\section{NSF greets 'a good budget'}

[WASHINGTON] The National Science Foundation (NSF), the main source of funds for non-medical research in US universities, would receive an increase of 3 per cent under President Clinton's proposals for the next financial year, increasing its budget to just under $\$ 3.4$ billion.

Science lobbying groups, which have set their sights on securing an increase of at least twice that amount, were quick to attack the proposal as inadequate. But Neal Lane, director of the foundation, said that it was "a good budget for the NSF, given the constraints" on overall government spending.

Under the proposal, the NSF will provide \$9 million for design work on the Millimetre Array, a proposed millimetre-wavelength telescope, and \$25 million for the Polar Cap Observatory near the North Pole. The proposals also include \$25 million towards renovation of NSF's ageing research stations at the South Pole, and \$10 million towards an initiative, personally backed by Clinton, to develop a 'second generation' Internet.

Lane declined to specify what NSF would have to give up to fund these new initiatives, merely saying that "we'll stop doing good things in order to do better things". But he promised to "discuss with the community where these cuts will take place".

The increase in the foundation's budget, which is basically sufficient to cover inflation, now running at 2 per cent in the

United States, will be spread evenly across the NSF's three main areas of activity research grants, research facilities and education. Of the agency's seven directorates, social sciences and computing fare best, with increases of 6.5 per cent and 7.6 per cent respectively. In contrast, geosciences lags with a proposed increase of just 1.5 per cent.

Cornelius Pings, president of the Association of American Universities, which earlier in the year joined with other science lobbying groups in calling for a 7.1 per cent increase for the NSF (see Nature 385, 103; 1997), says that he plans to continue to push the Congress for a larger increase.

Pings says he is "reasonably optimistic that we could end up with something more aggressive than what the president has put forward" for the agency.

Colin Macilwain

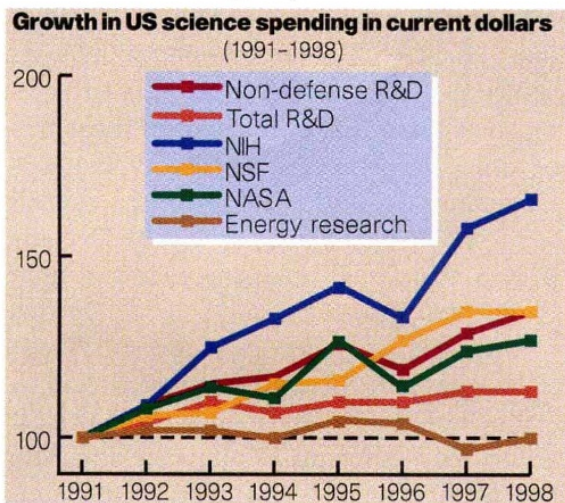

\title{
Green light sought for laser fusion and LHC
}

[WASHINGTON] Full funding for two major physics projects is included in the US energy department's budget proposal - the National Ignition Facility at Lawrence

Livermore National Laboratory in California, and the US contribution to the Large Hadron Collider at CERN in Switzerland.

The administration took the unusual step of asking for the entire $\$ 1$ billion needed to complete the National Ignition Facility which will test inertial confinement fusion to be given approval by Congress in the 1998 financial year. At the same time, it is seeking $\$ 450$ million for the collider over eight years under an 'advance appropriation' by which Congress would agree in principle to support the project to completion.

The collider request follows the conclusion last week of a framework agreement on the US contribution to the project. The deal was initialled by Martha Krebs, head of the energy department's Office of Energy Research, and Christopher Llewellyn Smith, director general of CERN, the European laboratory for particle physics in Geneva (see Nature 385, 103; 1997).

The department plans to increase its spending on research on detectors for the collider from $\$ 15$ million to $\$ 35$ million in 1998. The total budget for high-energy physics will remain virtually level at $\$ 675$ million. But money for the collider and other programmes will be released by this year's completion of the B-Factory at Stanford Linear Accelerator Center in California.

Nuclear physics will receive a budget increase of 5 per cent, to $\$ 332$ million, and basic energy sciences an increase of 4 per cent, to $\$ 672$ million. The latter includes $\$ 23$ million for the design of a proposed spallation neutron source at Oak Ridge, Tennessee.

In contrast, the administration is proposing to reduce it support for fusion science by 4 per cent, to $\$ 225$ million. But this total does include \$13 million towards the construction of a compact tokamak at Princeton Plasma Physics Laboratory in New Jersey.

Elsewhere, the administration found an extra $\$ 200$ million to boost research into solar and other renewable energy sources, as well as $\$ 100$ million for nuclear energy. Environmentalists welcomed the former, but criticized the latter as "wasteful and unnecessary corporate welfare".

\section{EPA seeks money for chemical clean-up}

The US Environmental Protection Agency is asking for $\$ 7.6$ billion next year, a 12 per cent increase over its 1997 budget. Much of that will be used to accelerate the clean-up of polluted chemical disposal sites. Science and technology spending will also grow significantly by 12 per cent, to $\$ 614$ million.

A considerable portion of the new science spending will go to strengthen research and monitoring of air pollutants, including ozone and fine particles. The agency plans to increase its spending slightly on grants to outside scientists to $\$ 100$ million.

\section{Biologists buck trend in Geological Survey}

The newly formed Biological Research Division, the successor to the US National Biological Service, is one of the few areas within the US Geological Survey to receive increased funding. The request for the division goes up slightly to $\$ 145$ million; overall the survey is seeking $\$ 745$ million for $1998, \$ 6.5$ million more than it received this year. Support for the survey's geological, mapping and water resources divisions would remain essentially flat.

\section{Basic research wins boost in defence}

The budget proposal increases basic research funded by the Department of Defense most of it conducted in universities - by 5 per cent, to $\$ 1.19$ billion. It also boosts funding for the Dual Use Application Programme, which develops technologies for both military and civilian use, from $\$ 181$ million to $\$ 225$ million. But, controversially, it cuts almost $\$ 800$ million from the $\$ 35$ billion that the department spends on developing equipment.

\section{Technology programme cuts back ambitions}

The Advanced Technology Programme operated by the National Institute of Standards and Technology would be raised from \$225 million to \$275 million, and the Manufacturing Extension Partnership from \$95 million to \$123 million, under the budget proposal. But the administration has shelved its previous ambitious plans to expand the ATP to a $\$ 1$ billion programme.

The budget requests flat funding for the institute's laboratories, and drops plans to replace lab buildings at Gaithersburg, Maryland and Boulder, Colorado. The National Oceanic and Atmospheric Administration, the other science agency in the Department of Commerce, is seeking an increase of 4 per cent, to $\$ 2$ billion. 